\title{
How Do Socio-Demographic Characteristics Affect Users' Perception of Place Quality at Station Areas? Evidence from Amsterdam, The Netherlands
}

\author{
Jinglun Du*(D), Oana Druta, Pauline van den Berg (D) and Pieter J. V. van Wesemael \\ Department of the Built Environment, Eindhoven University of Technology, \\ 5612 AZ Eindhoven, The Netherlands; o.druta@tue.nl (O.D.); p.e.w.v.d.berg@tue.nl (P.v.d.B.); \\ p.j.v.v.wesemael@tue.nl (P.J.V.v.W.) \\ * Correspondence: j.du1@tue.nl; Tel.: +31-649522596
}

Citation: Du, J.; Druta, O.; van den Berg, P.; van Wesemael, P.J.V. How Do Socio-Demographic Characteristics Affect Users' Perception of Place Quality at Station Areas? Evidence from Amsterdam, The Netherlands. Urban Sci. 2021, 5, 80. https:// doi.org/10.3390/urbansci5040080

Academic Editor: Mike Hynes

Received: 30 July 2021

Accepted: 15 October 2021

Published: 19 October 202

Publisher's Note: MDPI stays neutral with regard to jurisdictional claims in published maps and institutional affiliations.

Copyright: (C) 2021 by the authors Licensee MDPI, Basel, Switzerland. This article is an open access article distributed under the terms and conditions of the Creative Commons Attribution (CC BY) license (https:// creativecommons.org/licenses/by/ $4.0 /)$.

\begin{abstract}
Incorporating users' experiences in transport hub (re)development has become paramount, especially in the case of (high-speed) railway stations located in central urban locations. Designing "quality" according to users' perspectives requires that we rethink about the dimensions to be prioritized, but also consider the variegated perspectives of users. Drawing on data from a survey of 452 users of the Amsterdam Central station area in the Netherlands, the relative importance of three value perspectives (node, place, and experience) on place quality were assessed through exploratory factor analysis. Seven quality factors were identified. Furthermore, relationships between sociodemographic characteristics and quality perceptions were simultaneously analyzed using a path analysis. The outcome showed that age and gender play a key role in explaining different quality perceptions. Senior citizens attach a higher importance to basic needs and safety and advanced services, while women also find wayfinding important. Moreover, education and visiting purpose influence other aspects of place quality perception, such as shopping or transfer. These findings provide a better understanding of place quality considerations in railway station areas in general and can serve as guidelines for the improvement of Amsterdam Central station, in particular.
\end{abstract}

Keywords: place quality; user perspective; exploratory factor analysis; path analysis; railway station area

\section{Introduction}

Transforming station areas from "a node where people pass-through" to "a place where people can gather, work, play, and live" has become common sense [1]. As the connecting element between the station and its urban surroundings, public space in the station area needs to balance the node value and place values [2], to encourage people to walk and to consider public transport [3], as well as be enjoyable and comfortable [4]. This trend makes the quality of public space around stations a key point to tackle [5]. A growing number of studies state that the perceptions of users need to be prioritized $[4,6,7]$. Meanwhile, empirical studies show that place quality that fulfills users' expectation is seldom achieved, due to the complexity of user interaction with mobility infrastructures, amenities, and urban spaces [8]. Especially with the introduction of High-Speed Rail (HSR) services, the number of user groups increases, and their expectations for quality show an obvious diversity. Thus, it is especially important to understand users' experience in railway station areas in a comprehensive way [8,9].

It is also worth noting that recent publications on station areas predominantly frame user needs in terms of transit users' needs, namely, to improve onboard experience [10], to optimize transfer services [11,12], or to better integrate with other transport modes [13]. Therefore, they neglect the roles of shopping and leisure amenities in and around station areas $[4,14]$ for non-transit users. Some articles that have defined "good", "integrated", or 
"efficient" station areas provide insights into attributes that could be used to describe place quality [15,16], but only few studies directly examine the place quality of station areas [17]. "Hard to define, to reproduce, and to measure" [18], researchers and practitioners have acknowledged the challenge of investigating place quality in the context of transport hubs [19]. They have also pointed out that the examination of dimensions and indicators is an aid to grasp the immense complexity of the concept of quality [20].

Thus, this paper aims to contribute to two research gaps. First, to enrich the investigation of different user groups. Whether we recognize them as pedestrians, passers-by, passengers, customers, city dwellers, or neighborhood residents, they have all become the target groups of nowadays high-quality station areas [13,21]. This paper adopts the term "users" to include these varied target groups. Our second aim is to introduce and examine place attributes in order to rebalance scholarship currently dominated by a transport lens on quality. The main research questions are "How can the place quality of station areas be characterized from the perspective of users?" and "How is the perception of quality features related to the users' socio-demographic characteristics?" To address these questions, a survey was designed to relate quality dimensions of station areas, namely, wayfinding, transfer, safety, comfort, shopping, land use, and aesthetics, to users' perception and their socio-demographic characteristics. Exploratory factor analysis and path analysis were applied to the dataset.

For investigating place quality from the users' perspective, Amsterdam Central station (the Netherlands) was selected as the study case. The station, situated on the edge of the historic center, functions as the key transportation hub of the city, accommodating about 213,000 people a day [22], and serving multiple transport modes, including international rail lines, national rail lines, tram lines, metro lines, bus lines, ferry services, and HSR services. Although the HSR impact on Dutch station areas is considered as limited [23,24], Amsterdam Central station is still representative of HSR stations in Europe, namely the type that combines HSR services within conventional stations $[25,26]$. The station area has been undergoing major reconstruction and renovation works in the past two decades, including the station building, underground passages, metro and bus stations, and the surrounding public space. The public area within a $1 \mathrm{~km}$ radius around the station, including streets and squares, was defined in this study (Figure 1). Amsterdam Central station was chosen because quality improvement (including public space and amenities) of the whole station area was one of the main aims throughout its entire development process [26], making this case highly relevant to the study.

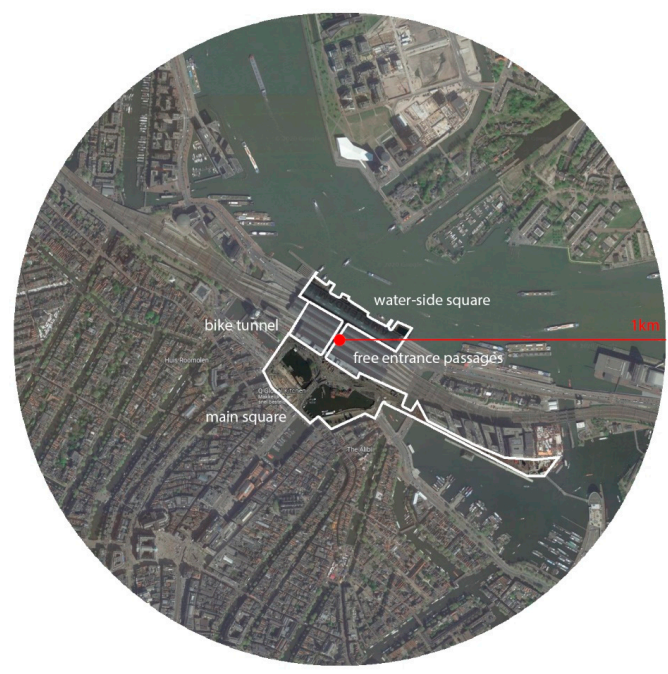

Figure 1. Study area defined as the public area within a $1 \mathrm{~km}$ radius around the station, including Stationsplein (main square), Waterplein (the water-side public space), and the free entrance passages under the railway platforms connecting the squares on both sides of the station (ticket-free indoor passage with commercial functions). 


\section{Place Quality in Station Areas and Its Dimensions}

This paper conceptualizes station areas as a hybrid between transit hub, central business district, and gateway to city life, highlighting seven dimensions of place quality that frame transit services, business and commercial activity, and the image value of station areas [27]. Building on Bertolini's node-place model, station areas exhibit both characteristics of a traffic node (emphasizing the transit services) and of urban place (emphasizing the economic development of surrounding urban space). While the original model equated the place value with economic activity, namely, the number of employees, commercial establishments, and office buildings, subsequent research has applied and extended this model, refining the functions of "urban place", and highlighting users' experiences of social life [28,29]. Groenendijk et al. [21] extended the node-place model with a third dimension: the experience lens that provides improvements of users' comfort. Next to the functional factor of making the transfer easier and reducing the waiting time, Hernandez and Monzon [15] identify the users' psychological perspective for an urban gateway experience-that is, to make the stay more comfortable. Zemp et al. [30] described station areas as having five generic functions which can be sorted into three perspectives: function as a traffic node that provides transit services (connecting catchment area and rail network, supporting intermodal transfer between modes), providing a place for business and social activities (facilitating commercial use, providing public space), and a gateway experience (shaping the place identity). Below, we apply these three perspectives to review the literature and identify the main dimensions/variables that structure the empirical part.

\subsection{Place Quality in the Context of Transit Services: Wayfinding and Transfer}

The concept of quality in relation to transportation hubs has been studied extensively from the transit services lens (frequency, ticket price, capacity, speed, information provision, and reliability) [31-33]. When it comes to place quality, the most important dimensions are associated with two types of physical environment that support transfer and wayfinding [34]. Primary physical environment attributes are those features that contribute to the walking experience [35], such as outdoor space layout [36,37], accessibility [38], surrounding traffic conditions [39], and crowding [40]. The attributes related to transfer include transport modes, distance/time, and facilities that support the transfer, such as ticket machines, bike parking, and the presence of kiss and ride facilities [41-44]. These two dimensions are usually studied together. For example, Abreu e Silva and Bazrafshan's study [32] demonstrated that satisfaction with transport interchanges was significantly influenced by the signage system (transfer) and streetscape (wayfinding). Table 1 shows how the place quality indicators for wayfinding and transfer from the literature review were summarized in the study.

Table 1. Wayfinding and transfer indicators measured in survey.

\begin{tabular}{|c|c|c|}
\hline Dimension & Definition & Indicators \\
\hline Wayfinding & $\begin{array}{l}\text { The spatial configuration of the } \\
\text { station area and walking } \\
\text { experience. }\end{array}$ & $\begin{array}{c}\text { Entrances and exits of the station building } \\
\text { Visual connection } \\
\text { Pedestrian experience } \\
\text { Traffic conditions (vehicles) } \\
\text { Crowdedness/ liveliness (pedestrians) }\end{array}$ \\
\hline Transfer & $\begin{array}{c}\text { How smooth and easy a user } \\
\text { could switch between modes, } \\
\text { including options, distance, and } \\
\text { amenities. }\end{array}$ & $\begin{array}{l}\text { Multiple modes } \\
\text { Transfer distance } \\
\text { Ticket machine } \\
\text { Kiss and ride } \\
\text { Elevators and escalators }\end{array}$ \\
\hline
\end{tabular}

\subsection{Place Quality in the Context of Places for Business Activities: Land Use Diversity and Shopping}

Station areas are central locations for office, culture, and commerce development, taking advantage of the high degree of connectivity provided by the presence of the 
transport hub. As such, station areas usually perform the role of a central business district within the urban structure. Land use diversity and the quality of shopping experience are the two dominant dimensions of place quality that have been identified in the literature in relation to this function (Table 2) $[19,45]$. In addition to the mix of public functions, housing and jobs were particularly emphasized in Table 2 since the unique character created by the presence of different pedestrians (singles/families, white/blue collar workers, tourists, etc.) can be tangibly perceived by station users [46].

Table 2. Land use and shopping indicators measured in survey.

\begin{tabular}{ccc}
\hline Dimension & Definition & Indicators \\
\hline \multirow{3}{*}{ Shopping } & The possibilities and & Attractiveness of shops \\
& Diversity of shops \\
& attractiveness of shopping & Extended open hours \\
Land use & Land use diversity & A mix of public functions (e.g., retail, education, \\
& & Advertisements \\
& & institutional, sports, and recreation) \\
& & Diversity of jobs \\
\hline
\end{tabular}

From a land use perspective (macro), the density of inhabitants, the density of jobs and amount of retail/residential/commercial/recreational land use, and amount of open space have become common indicators [47-50], representing urban characteristics and development capacity in station areas [51]. Abdul Rahman [52] highlighted that businesses and commercial activities are the strongest functions that contribute to the liveliness of streets. By means of a questionnaire in Tokyo's large railway terminals, Li, Yamamoto, and Morikawa [53] verified the importance of different types of shops at station areas producing different atmospheres. From a micro, user-oriented perspective, successful retail at station areas is often associated with the number, attractiveness, and diversity of shops [54-57].

\subsection{Place Quality and Gateway Experience: Aesthetics, Comfort, and Safety}

Last, as gateways to city centers, the atmosphere, image, and design of public spaces around stations have been involved in the discussions of "quality at station areas" for enhancing the sense of place and gathering people [56-59] (Table 3). Public space attached to stations has been studied mostly from a design perspective [60]. Hernandez and Monzon [15] defined the experience of using a station as the internal and external design characteristics. Studying Chinese station areas, Wang [61] emphasized the permeability, and legibility of the surrounding square as important factors for public life. Dai, Jia, and Lv [62] further detailed the aesthetic factors of station squares as spatial scale, plants configuration, landscape, atmosphere, and environment. Cascetta and Cartenì [7] found a correlation between the passengers' willingness to walk and perceptions of aesthetic quality at the station, such as building construction and architectural quality. Duckworth-Smith and Babb [63] utilized the presence of public spaces, features that contribute to distinctive character, and landmarks that contribute to legibility to analyze the public realm quality.

For some difficult-to-understand, intangible concepts (for respondents), these studies have also made efforts to qualitatively interpret them [21,53]. For example, by consulting an expert panel, Ewing and Handy [64] further defined urban design qualities such as "imageability, enclosure, human scale, transparency and complexity" as measurable indicators: outdoor dining, noise level, proportion street wall/sky, pieces of street furniture, opening time, and pieces of public art. 
Table 3. Comfort, aesthetics, and safety indicators measured in survey.

\begin{tabular}{|c|c|c|}
\hline Dimension & Definition & Indicators \\
\hline Comfort & $\begin{array}{c}\text { The presence, numbers, and maintenance of } \\
\text { amenities, used by people spending longer time } \\
\text { in the station area. }\end{array}$ & $\begin{array}{c}\text { Phone charging station } \\
\text { Wi-Fi } \\
\text { Outdoor space to sit and linger } \\
\text { Accessibility facilities } \\
\text { Kids play zone } \\
\text { Noise level } \\
\text { Air quality } \\
\text { Trash bin } \\
\text { Food and drinks } \\
\text { Toilet facilities } \\
\text { Lockers } \\
\text { Shelter from wind, rain, and cold } \\
\text { Temperature and ventilation }\end{array}$ \\
\hline Aesthetics & $\begin{array}{l}\text { Architectural design, landmarks, and other } \\
\text { landscape features perceived by users }\end{array}$ & $\begin{array}{c}\text { Quality of station squares } \\
\text { Landmarks and architecture } \\
\text { Streetscape (facade continuity, human scale design, etc.) } \\
\text { Public art } \\
\text { Quality of furnishing and decoration }\end{array}$ \\
\hline Safety & $\begin{array}{l}\text { The environmental supervision, such as lighting, } \\
\text { presence of police and staffs, as well as } \\
\text { maintenance of spaces }\end{array}$ & $\begin{array}{c}\text { Well-maintained amenities } \\
\text { Good lighting } \\
\text { Priority for pedestrians over cars } \\
\text { No dead-ends } \\
\text { Help in an emergency (existence of police and staff) } \\
\text { Presence of other people }\end{array}$ \\
\hline
\end{tabular}

In addition to listing the above influencing factors, researchers identify safety as an overarching dimension of quality, followed by the other advanced qualities [31,60,65-67]. A survey conducted by Iseki and Taylor [68] has also expressed a similar view. They concluded that the most important determinant of user satisfaction was associated with safety. When failing to meet the basic needs, a station area cannot fulfill any additional quality desiderates, because people will avoid the area in principle. Specific attributes related to safety [69] are listed below (Table 3).

Another insight is that the complexity of user perception has been acknowledged. Quality itself connotes a somewhat subjective evaluation of a person, object, or situation [70]. It follows that place quality is multifaceted and ambiguous with diverging meanings for different groups of users and stakeholders with different agendas [53,71,72]. Akiyama [73] analyzed the composition of railway users in the Keihanshin metropolitan area and identified the differences in travel behavior by age groups. Cascetta and Cartenì [7] conducted a quantitative analysis to investigate the hedonic value and concluded that female travelers paid more attention to the aesthetics quality of station building than male travelers. Hernandez et al. [74] designed a survey to understand the emotional responses of different types of users on various aspects of an interchange, for example, perception of safety and pleasantness. Although some studies partly discussed the effects of socio-demographic (e.g., age and gender) and trip characteristics (e.g., travel distance, time of transfer) on some aspects of place quality, the exploration is still inadequate, since many dimensions of place quality have not attracted as much attention as the transit quality, particularly from a social/experiential perspective [75].

\subsection{Research Questions}

Drawing on these insights, the article adopts an exploratory approach to address two research questions: (1) How do station area users perceive place quality with respect to seven dimensions: wayfinding, transfer, safety, comfort, land use, aesthetics, and shopping? (Figure 2) (2) How do different groups of users in terms of socio-demographic and visit 
characteristics (refer to visiting purpose and frequency) perceive quality features at station areas? To study the place quality of the station areas, the following conceptual model was developed, covering the major quality dimensions of station areas discussed above.

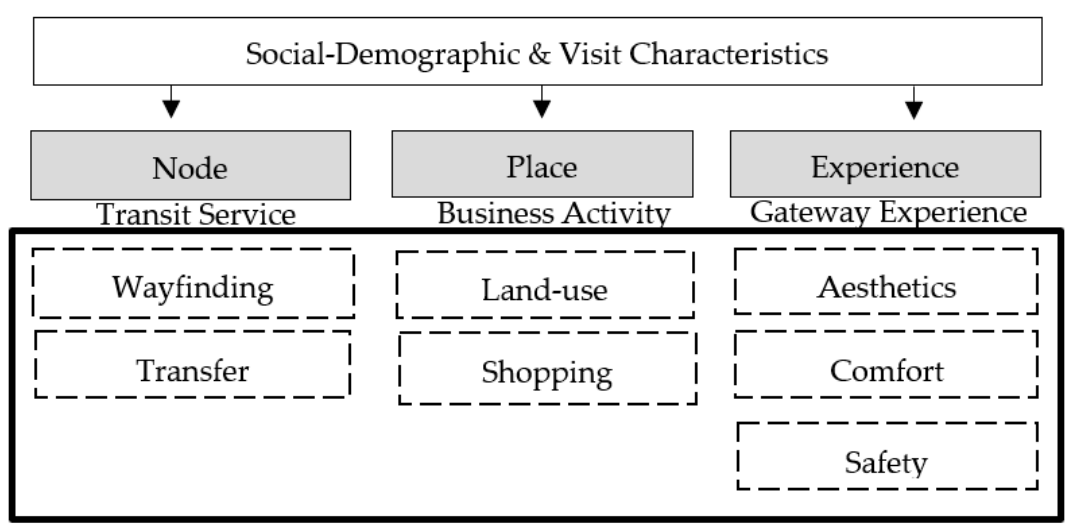

Overall Quality Perception

Figure 2. Conceptual model.

\section{Methodology}

This study aimed to analyze the main dimensions explaining users' perception of place quality at a station area and to further investigate the relations between dimensions and users' characteristics by way of a quantitative survey. Using the Amsterdam Central station area as a case study, first, exploratory factor analysis (EFA) was applied to reveal the underlying structure of 48 indictors from seven proposed dimensions. Then, relationships between socio-demographics and the verified seven quality factors were simultaneously investigated by estimating a path model in AMOS 20 software program. Path analysis was valuable to the current investigation because it allowed us to measure the multidimensional construct and simultaneously examine the complexities of a series of relationships [76-79]. Last, the study employed I-S Analysis to identify the attributes to be prioritized for quality improvements in the case of Amsterdam Central Station.

\subsection{Survey Design}

The survey consisted of three parts: (1) screening questions that aimed to exclude non-target respondents who are not familiar with the studied area, based on their visiting purpose and frequency; (2) users' perceived importance of seven dimensions of place quality and the level of satisfaction with the same indicators within Amsterdam Central station area; each dimension ended with an open question, "are there any other elements not listed above that you consider important?", to collect the potential missing indicators; and (3) the socio-demographic characteristics. Respondents' perception of quality regarding the seven dimensions and the indicators in each dimension were measured with a 3-point scale (1-unimportant, 2-neutral, 3-important). The level of satisfaction with the place quality was measured as well with a 3-point Likert scale (1-dissatisfied, 2-neutral, 3-satisfied). Before distributing the survey, a pilot survey of 14 students and scholars with experience in the field was conducted. The number of questions and questionnaire style was improved based on this phase. Further explanations were added to terms that respondents may not be familiar with. For example, "eyes on the streets" was explained as "the presence of other people that keep you feel safe and secure", and "visual connection" was explained as "imagine a boulevard leading to a station that guides you to easily see the existence of station".

\subsection{Data Collection}

At the time of conducting this survey (spring of 2021), public transport use was sharply restricted by the Dutch authorities to combat COVID-19. Therefore, the survey 
was conducted online through a citizen panel of the municipality of Amsterdam. For the sample, 10 postcode zones within walking distance to the station were selected. To avoid the impact of the COVID-19 epidemic, only users who are still using the station area during the epidemic and who claim to know the study area well because they either work or live in the area were included in the study. Surveys were conducted in Dutch. In total, 521 questionnaires were retrieved, from which 452 were considered valid responses. Within the sample of station area users, "transfer" (53.3\%) and "living in the station area" $(39.4 \%)$ were the main visiting purposes (Table 4). A higher proportion of respondents having a medium income (1751-4000 EUR/month, 46.2\%) made up the sample, while the proportions of low-income (less than EUR 1750) and high-income users (more than EUR $4001)$ were evenly distributed $(\approx 25 \%)$. Just over half of respondents were male $(53.3 \%)$. In terms of age, the sample was relatively old, with the majority of survey participants (57.3\%) between 36 and 65 years old, followed by $33.6 \%$ above age 66 . Although a second round of questionnaires targeting users under 35 was launched, users under 35 years old comprised a smaller proportion $(9.1 \%)$ of the sample. This is due to the characteristics of the citizen panel, which is biased toward older residents. This fact should be considered in subsequent interpretations of the findings.

Table 4. Socio-demographic and visiting characteristics.

\begin{tabular}{|c|c|c|}
\hline Characteristics & Sample Size & $\%$ \\
\hline Valid response & 452 & 100 \\
\hline $\begin{array}{c}\text { Visiting purpose } \\
\text { Living at the station area } \\
\text { Working at the station area } \\
\text { Transfer }\end{array}$ & $\begin{array}{c}178 \\
33 \\
241\end{array}$ & $\begin{array}{c}39.4 \% \\
7.3 \% \\
53.3 \%\end{array}$ \\
\hline $\begin{array}{l}\text { Visiting frequency } \\
\text { At least once per day } \\
\text { At least once per week } \\
\text { At least once per month } \\
\text { At least once per year }\end{array}$ & $\begin{array}{c}32 \\
150 \\
203 \\
67\end{array}$ & $\begin{array}{l}7.1 \% \\
33.4 \% \\
44.9 \% \\
14.8 \%\end{array}$ \\
\hline $\begin{array}{c}\text { Gender } \\
\text { Female } \\
\text { Male }\end{array}$ & $\begin{array}{l}211 \\
241\end{array}$ & $\begin{array}{l}46.7 \% \\
53.3 \%\end{array}$ \\
\hline $\begin{array}{c}\text { Ethnicity } \\
\text { Non-western foreigners } \\
\text { Western foreigners } \\
\text { Natives }\end{array}$ & $\begin{array}{c}26 \\
70 \\
356\end{array}$ & $\begin{array}{l}5.8 \% \\
15.5 \% \\
78.8 \%\end{array}$ \\
\hline $\begin{array}{c}\text { Age (median age: } 57 \text { years old) } \\
\text { Youth: Under } 35 \\
\text { Adult: } 36-65 \\
\text { Senior: Above } 66\end{array}$ & $\begin{array}{c}41 \\
259 \\
152\end{array}$ & $\begin{array}{l}9.1 \% \\
57.3 \% \\
33.6 \%\end{array}$ \\
\hline $\begin{array}{l}\text { Income per month } \\
\text { Low (Under 1750) } \\
\text { Medium (1751-4000) } \\
\text { High (Above 4001) }\end{array}$ & $\begin{array}{l}129 \\
209 \\
114\end{array}$ & $\begin{array}{l}28.5 \% \\
46.2 \% \\
25.2 \%\end{array}$ \\
\hline $\begin{array}{c}\text { Education } \\
\text { Low }\left(\text { Elementary, } \mathrm{VMBO}^{1}\right) \\
\text { Medium }\left(\mathrm{HAVO}^{2}, \mathrm{VWO}^{3}\right) \\
\text { High }\left(\mathrm{MBO}^{4}, \mathrm{HBO}^{5}, \mathrm{WO}^{6}\right)\end{array}$ & $\begin{array}{c}11 \\
67 \\
374\end{array}$ & $\begin{array}{l}2.4 \% \\
14.8 \% \\
82.8 \%\end{array}$ \\
\hline $\begin{array}{l}\text { Household composition } \\
\text { Single } \\
\text { Adults with child(ren) } \\
\text { Adults without child(ren) }\end{array}$ & $\begin{array}{c}204 \\
170 \\
78\end{array}$ & $\begin{array}{l}45.1 \% \\
37.6 \% \\
17.3 \%\end{array}$ \\
\hline
\end{tabular}

Note: ${ }^{1}$ Middle-level applied education ("voorbereidend middelbaar beroepsonderwijs: VMBO"); ${ }^{2}$ higher general continued education ("hoger algemeen voortgezet onderwijs: HAVO"); ${ }^{3}$ preparatory scholarly education ("voorbereidend wetenschappelijk onderwijs: VWO"); ${ }^{4}$ vocational education ("middelbaar beroepsonderwijs: $\left.\mathrm{MBO}^{\prime \prime}\right) ;{ }^{5}$ vocational education ("hogerberoeponderwijs: HBO") ${ }^{6}$ higher education ("wetenschappelijk onderwijs: $\mathrm{WO}^{\prime \prime}$, universiteit, gepromoveerd). 


\section{Results and Interpretation}

\subsection{Exploratory Factor Analysis}

To detect whether underlying structures match with the seven dimensions studied, EFA was applied on the perceived importance data of 48 indictors. Factor extraction was carried out using a factor interpretability criterion, so variables with factor loadings lower than 0.4 were eliminated [80]. Eventually, 39 indictors were clustered. The data structure is consistent and explained more than $50 \%$ of the variance with a KMO value greater than 0.5 [80]. In total, EFA generated seven factors (Table 5). The "wayfinding", "transfer", and "shopping" dimensions remained constant. The "comfort" dimension was extracted into two groups. Part of comfort indicators combined with the "safety" dimension, named "basic needs", focusing on the presence and conditions of facility attributes/safety qualities that allow users to stay, the rest of the comfort indictors were named "advanced services" to describe the qualities that support non-commuting purposes, such as entertainment and social activities. The Cronbach's alpha scores were acceptable [81].

Table 5. EFA results.

\begin{tabular}{|c|c|c|c|c|c|}
\hline Dimension & Factors & Code & Indicators & Factor Loading & Cronbach's Alpha \\
\hline & (Total varian & explaine & 1.153\%; KMO: 0.781; Bartlett's Test of Sphe & : Approx. Chi-Squ & e: 5827.957, df: 1128$)$ \\
\hline \multirow{5}{*}{ Wayfinding } & \multirow{5}{*}{ Wayfinding } & W1 & Visual connection & 0.692 & \multirow{5}{*}{0.621} \\
\hline & & W2 & Traffic conditions (vehicles) & 0.560 & \\
\hline & & W3 & Crowdedness / liveliness (pedestrians) & 0.560 & \\
\hline & & W4 & Distance between modes & 0.573 & \\
\hline & & W5 & Priority for pedestrians over cars & 0.465 & \\
\hline \multirow{5}{*}{ Transfer } & \multirow{5}{*}{ Transfer } & $\mathrm{T} 1$ & Transfer options & 0.588 & \multirow{5}{*}{0.568} \\
\hline & & $\mathrm{T} 2$ & Kiss and ride & 0.490 & \\
\hline & & T3 & Transfer time & 0.481 & \\
\hline & & $\mathrm{T} 4$ & Ticket machine & 0.419 & \\
\hline & & T5 & Bike facilities & 0.416 & \\
\hline \multirow{6}{*}{ Shopping } & \multirow{6}{*}{ Shopping } & S1 & Diversity of shops & 0.858 & \multirow{6}{*}{0.868} \\
\hline & & S2 & Attractiveness of shops & 0.843 & \\
\hline & & S3 & Number of stores & 0.841 & \\
\hline & & S4 & Extended opening hours & 0.808 & \\
\hline & & S5 & Distance between stores & 0.681 & \\
\hline & & S6 & Ads & 0.449 & \\
\hline \multirow{6}{*}{ Aesthetics } & \multirow{3}{*}{$\begin{array}{l}\text { Art and } \\
\text { decoration }\end{array}$} & D1 & Public arts & 0.588 & \multirow{3}{*}{0.551} \\
\hline & & $\mathrm{D} 2$ & Quality of furnishings and decoration & 0.531 & \\
\hline & & D3 & Air quality and noise level & 0.493 & \\
\hline & \multirow{6}{*}{$\begin{array}{l}\text { Land use } \\
\text { and } \\
\text { architecture }\end{array}$} & L1 & Quality of station squares & 0.821 & \multirow{6}{*}{0.790} \\
\hline & & L2 & Streetscape & 0.805 & \\
\hline & & L3 & Architecture and landmarks & 0.747 & \\
\hline \multirow{3}{*}{ Land use } & & L4 & Different housing types & 0.552 & \\
\hline & & L5 & Diversity of jobs & 0.601 & \\
\hline & & L6 & $\begin{array}{l}\text { A mix of public functions (e.g., retail, } \\
\text { education, institutional, sports, } \\
\text { and recreation) }\end{array}$ & 0.604 & \\
\hline
\end{tabular}


Table 5. Cont.

\begin{tabular}{|c|c|c|c|c|c|}
\hline Dimension & Factors & Code & Indicators & Factor Loading & Cronbach's Alpha \\
\hline \multirow{8}{*}{ Comfort } & \multirow{4}{*}{$\begin{array}{l}\text { Advanced } \\
\text { services }\end{array}$} & A1 & Wi-Fi & 0.623 & \multirow{4}{*}{0.626} \\
\hline & & A2 & Phone charging station & 0.619 & \\
\hline & & A3 & Lockers & 0.562 & \\
\hline & & A4 & Outdoor space to sit and linger & 0.500 & \\
\hline & \multirow{10}{*}{$\begin{array}{l}\text { Basic needs } \\
\text { and safety }\end{array}$} & B1 & Good lighting & 0.718 & \multirow{10}{*}{0.649} \\
\hline & & B2 & Well-maintained amenities & 0.528 & \\
\hline & & B3 & Shelter from wind, rain and cold & 0.518 & \\
\hline & & B4 & Trash bin & 0.515 & \\
\hline \multirow{6}{*}{ Safety } & & B5 & Existence of other people & 0.490 & \\
\hline & & B6 & No dead-ends & 0.466 & \\
\hline & & B7 & $\begin{array}{l}\text { Help in an emergency (existence of police } \\
\text { and staff) }\end{array}$ & 0.416 & \\
\hline & & B8 & Elevators and escalators & 0.392 & \\
\hline & & B9 & Toilet facilities & 0.384 & \\
\hline & & B10 & Food and drinks & 0.320 & \\
\hline
\end{tabular}

Through EFA, seven factors that refined the original conceptual framework were extracted (Figure 3), providing a more precise way of interpreting users' perceptions of important factors for place quality.

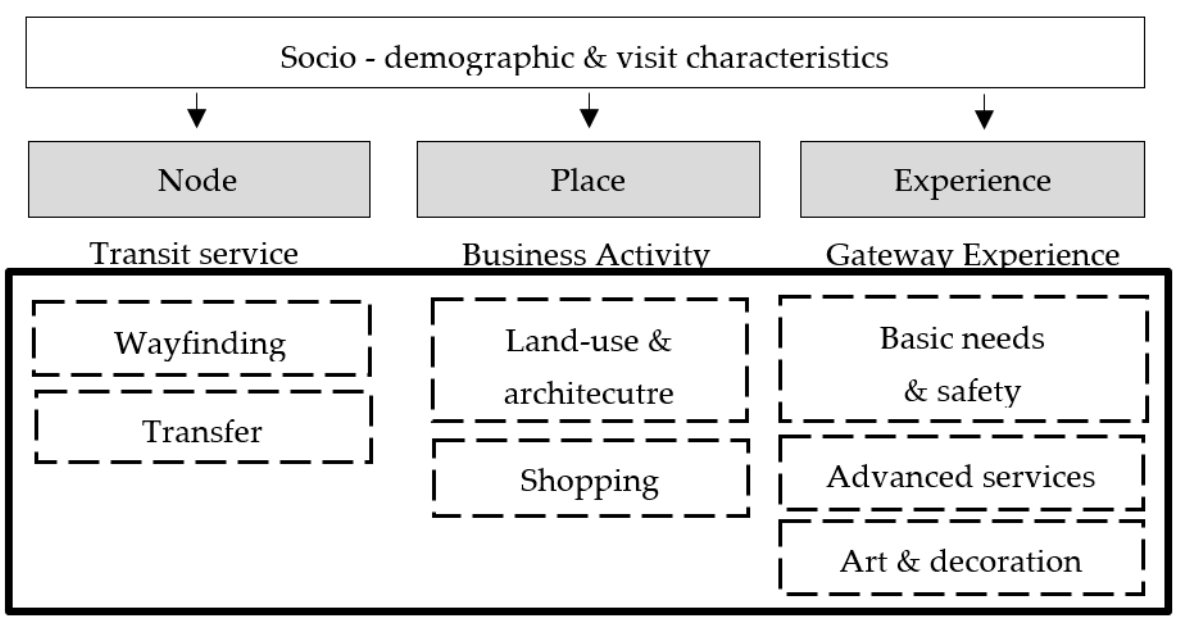

Overall Quality Perception

Figure 3. Revised conceptual model.

\subsection{Path Analysis}

To simultaneously assess the relationships between the seven place quality factors and users' socio-demographic and visit characteristics, a path analysis model was applied. First, corresponding to the number of quality factors extracted from EFA, seven endogenous variables were entered in the model, namely, wayfinding, transfer, shopping, basic needs and safety, advanced services, land use and architecture, and art and decoration. Since socio-demographic and visit characteristics were measured by categorical variables, all eight of them were recoded into dummy variables. Then, all socio-demographics as exogenous variables and links between all socio-demographic variables and the seven place quality factors were added. The links between the seven endogenous variables were 
not created, as it is not the intention of this study to use importance of one dimension to explain the importance of another place dimension. The maximum likelihood method was used to estimate the models. To reduce the number of links in the model and to avoid overfitting the model, the links that were not found to be significant (at the 0.05 significance level) in the path model were subsequently removed until a model was estimated with only significant relationships. In the final model, one of the factors (land use and architecture) was removed, as it was not significantly related to any of the exogenous variables. While we tested for correlations between the error terms of the seven endogenous variables, none of them were significant. Eventually, the model was evaluated by using multiple fit indices (Table 6), including the goodness of fit index (GFI), adjusted goodness of fit index (AGFI), incremental fit index (IFI), Akaike information criterion (AIC), and root mean square error of approximation (RMSEA). All indices reached the recommended values [82], implying suitable quality of the overall model. The final model with significant variables and the standardized coefficients of the path are presented in Figure 4.

Table 6. Model fitting.

\begin{tabular}{cccccccc}
\hline CMIN & df & CMIN/df & RMSEA & GFI & AGFI & IFI & AIC \\
\hline 130.629 & 52 & 2.512 & 0.058 & 0.957 & 0.936 & 0.913 & 182.629 \\
\hline
\end{tabular}

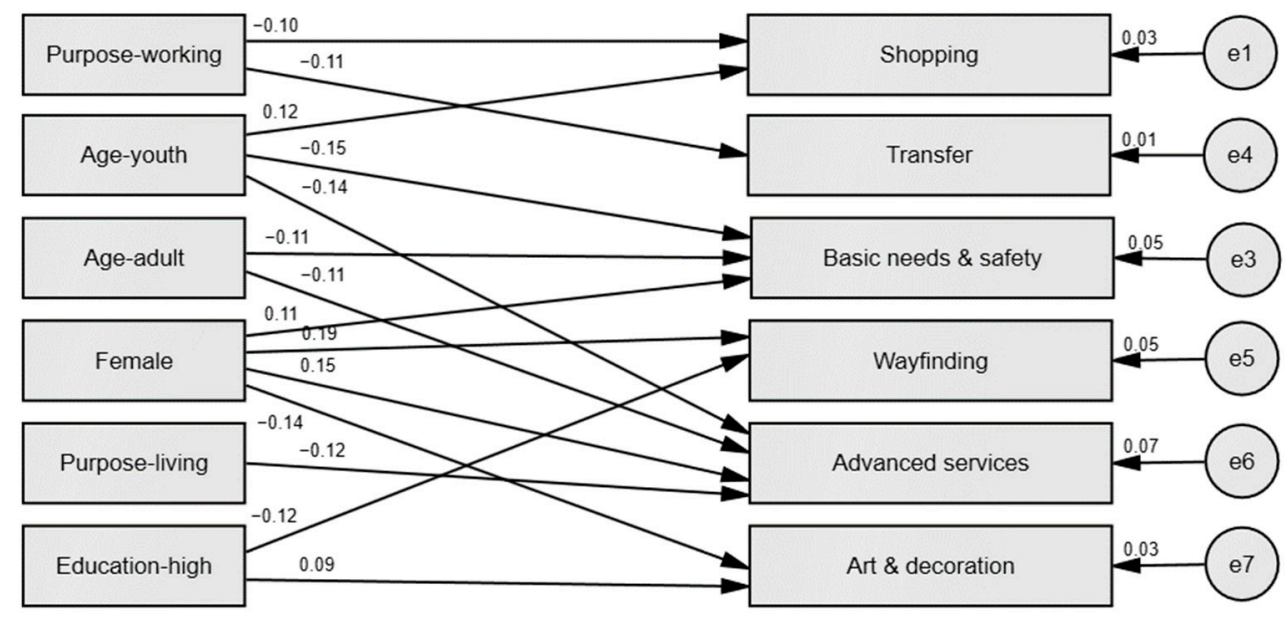

Figure 4. Structure of the model.

\subsection{Model Results}

Table 7 presents the results of the path model, which explain the significant impact of socio-demographic characteristics on quality perceptions. The results demonstrate that gender, age, education, and visit purpose have significant effects on six of the factors, except land use and architecture, implying that the perceived importance of place quality varies among individuals. The current study did not show any significant effects of income, ethnicity, household composition and visit frequency on quality perception.

The results show that women attributed higher perceived importance to wayfinding, basic needs, safety, and advanced services compared to men. Among these four factors, wayfinding showed the largest path coefficient (0.372), followed by advanced services (0.310). This result is consistent with former research. Women, in general, tend to seek more diverse services and functions than men [83]. Ng and Acker [84] interpreted this special attention as connected to the multiple purposes of women's use of transportation-that is, in addition to commuting, women make more non-work-related trips for domestic tasks such as care duties or errands. Thus, women are likely to benefit from the presence of advanced services. In terms of wayfinding, studies found that women often show lower spatial navigation performance than men [85]. In addition, different transport behaviors between genders may help to explain why a stronger correlation between women and 
their perceived importance of wayfinding exists. According to Irschik and Kail [86], women tend to conduct more trips per day than men, spending more time on navigation; correspondingly, they may find it more important. One result that seems to contradict common sense is that women attribute less importance to art and decoration. One possible explanation might be that in an overwhelming site such as a station area, women tend to focus on functional aspects, such as wayfinding, basic needs, etc. This finding points to possible further investigation.

Table 7. Results of path analysis (only significant results included).

\begin{tabular}{|c|c|c|c|c|c|c|c|c|c|c|c|c|}
\hline \multirow{3}{*}{ Intercept } & \multicolumn{2}{|c|}{ Wayfinding } & \multicolumn{2}{|c|}{ Transfer } & \multicolumn{2}{|c|}{ Shopping } & \multicolumn{2}{|c|}{$\begin{array}{l}\text { Advanced } \\
\text { Services }\end{array}$} & \multicolumn{2}{|c|}{$\begin{array}{c}\text { Basic Needs and } \\
\text { Safety }\end{array}$} & \multicolumn{2}{|c|}{$\begin{array}{c}\text { Art and } \\
\text { Decoration }\end{array}$} \\
\hline & \multicolumn{2}{|c|}{-0.124} & \multicolumn{2}{|c|}{0.032} & \multicolumn{2}{|c|}{-0.011} & \multicolumn{2}{|c|}{0.133} & \multicolumn{2}{|c|}{0.071} & \multicolumn{2}{|c|}{0.091} \\
\hline & Estimates & S.E. & Estimates & S.E. & Estimates & S.E. & Estimates & S.E. & Estimates & S.E. & Estimates & S.E. \\
\hline Female & $0.372 * * *$ & 0.092 & & & & & $0.310^{* * *}$ & 0.092 & $0.222 *$ & & $-0.278 * *$ & 0.093 \\
\hline $\begin{array}{l}\text { Age-young } \\
\text { Age-adult }\end{array}$ & & & & & $0.433 * *$ & 0.162 & $\begin{array}{l}-0.500 * * \\
-0.233 *\end{array}$ & $\begin{array}{l}0.172 \\
0.100\end{array}$ & $\begin{array}{l}-0.522 * * \\
-0.223\end{array}$ & $\begin{array}{l}0.174 \\
0.101\end{array}$ & & \\
\hline Education-high level & $-0.339 * *$ & 0.129 & & & & & & & & & $0.265^{*}$ & 0.131 \\
\hline $\begin{array}{l}\text { Purpose-living } \\
\text { Purpose-working }\end{array}$ & & & $-0.438 *$ & 0.180 & $-0.392 *$ & 0.178 & $-0.251 * *$ & 0.094 & & & & \\
\hline
\end{tabular}

Note: S.E., standard errors. All estimates are unstandardized. ${ }^{*} p<0.1$, significant at the $10 \%$ level. ${ }^{* *} p<0.05$, significant at the $5 \%$ level. *** $p<0.01$, significant at the $1 \%$ level.

Significant differences between age groups were identified for three factors, namely, shopping, basic needs, and advanced services. A general pattern was discovered: with age, users attach more importance to "safety" and "comfort" qualities. Some previous studies reached a similar conclusion that with age-induced visual and cognitive impairments, users require more help in terms of using traffic nodes in a comfortable and safe way $[87,88]$. Young users attributed higher importance to shopping. One previous study showed that age has a statistically significant association with shopping responsibility-that is, younger respondents are more likely to share shopping responsibility [89].

Users working in the station area showed the lowest perceived importance of shopping, transfer, and advanced services. This is an intuitive result since they have a definite purpose of visiting [90,91], and their extra needs might be fulfilled by the office buildings located close by the station areas rather than station area itself.

As we can see from the coefficients, users with high education give less importance to wayfinding. This probably relates to the fact that people with a higher education usually frequently use their bike in Amsterdam [92], which requires less experience with wayfinding due to lower speeds and the possibility of adjusting routes. Meanwhile, users with high education consider aesthetics more important compared with other sub-groups. This can be explained by the fact that higher educated people more often associate place aesthetics with the quality of their experience of that place [93].

Finally, though we expected quality perception to differ according to ethnicity, household composition, and, especially, visit frequency, these characteristics did not show any significant links, which means that all seven factors were important irrespective of the ethnicity, household composition, and frequency of visit. We speculate this may be related to the dominance of local residents in the survey which precluded a more nuanced consideration of the diversity of non-local visitors. Furthermore, the travel restrictions during the COVID-19 pandemic influenced the frequency of visits to the station and the way people related to the space. This encourages possible further study applying more extensive and detailed socio-demographic data.

To sum up, the path analysis allowed us to better interpret different quality perceptions among varied types of users, and consequently, to prioritize various target groups to improve the overall perceived place quality of station areas. Some general principles about place quality should be considered in station areas. After fulfilling the needs of all types of users, extra focus on basic needs and safety and advanced services would improve the experiences of seniors and female users, while wayfinding is especially important for 
female users. When considering shopping quality, the opinions of youth, nearby residents, and commuters should be taken into consideration. In terms of advanced services, women, seniors, and nearby residents can benefit more from more non-travel-oriented services, given that these groups attached more importance to these aspects in their use of station areas. These results are potentially practical since they can indicate possible actions for planners and municipal administrators to improve the place quality to station areas, and to enhance users' experience.

\section{I-S Analysis}

After forming a general impression of place quality, I-S Analysis was conducted, utilizing both the perceived importance and the satisfaction data in the survey, to provide more location tailored recommendations for the Amsterdam Central station area. Since it has been undergoing renovation, specific actions and attention can be prioritized based on their relative urgency of improvement [34,94]. Figure 5 shows in quadrant 1 elements of place quality that require "continued emphasis". Items that constitute potential "areas of improvement" are shown in quadrant 2. Quadrant 3 shows elements of place quality that "exceed expectations" in the eyes of users. Finally, quadrant 4 shows "lower priority" items.

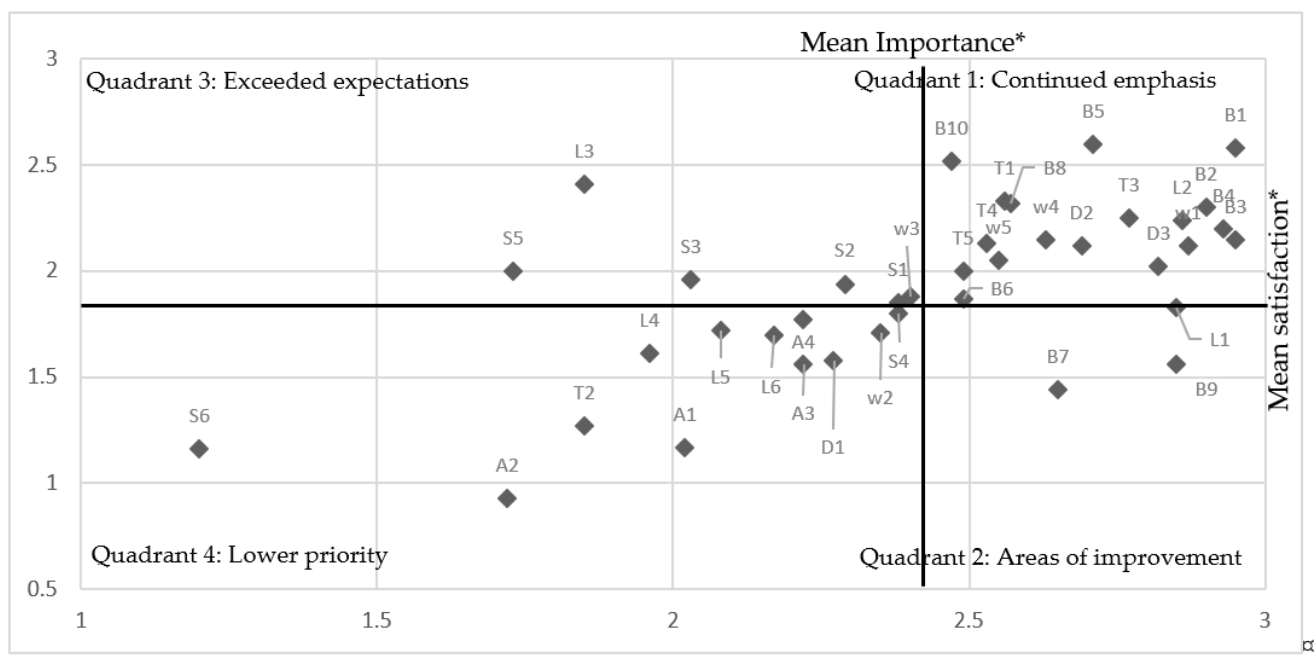

Figure 5. I-S analysis of the place quality. Note: The reference of importance and satisfaction in Figure 5 was the mean of " $3=$ important/satisfied" given by respondents to the survey.

The I-S analysis demonstrated that in general, Amsterdam Central station area satisfies users' expectations of place quality. Among the 39 selected indicators, 17 of them landed in quadrant 1 , "continued emphasis". Specifically, out of the seven factors we summarized in Section 4, basic needs and safety (B1-5, 8, and 10), transfer (T1,3, 4, and 5), and wayfinding (W1, 4, and 5) were perceived as well performing in the context of Amsterdam Central station area and should continue to be monitored to keep satisfaction high.

Quadrant 2 presents the attributes that users found important but were less satisfied with. Help in an emergency (B7), toilet facilities (B9), and quality of station square (L1) are located in this quadrant. Observations regarding basic needs and safety can also be found in respondent's comments in open-structured questions. For example, "As a woman, I get an unsafe feeling when coming alone by train late at night, and there is no staff still working in the station building and nearby shops". The complaints about basic facilities and the station square could be related to ongoing renovations that have been frustrating users' experience with the station area for decades. Quotes from respondents include: "There have been major renovations around the station for years now. The signage around these activities is not always clearly indicated", "There are parts of the elevator entrances that get very slippery when it rains, so there is a great risk of falling for seniors", "In any case, public toilets in Amsterdam are quite few and never clearly visible. Especially now 
during the renovation, you notice that it is difficult to find toilet facilities during a walk. And there are often long lines at the sanitary facilities, this should be improved". Although it should be noted that this conclusion may be caused by the respondents' bias towards the elderly, Amsterdam Central could still profit from improving these aspects such as increasing the number of signs and toilets and improving the accessibility facilities on station square.

In quadrant 3, "exceeded expectation", four out of six indicators of shopping, with two exceptions are located: extended open hours (S4) and advertising (S6), considered as lower priority. This indicates that users' attitudes towards shopping are complicated. On the one hand, people enjoy the convenience of having diverse shops nearby the station. On the other hand, they do not expect the existence of shops and advertising to affect their transfer quality. Quotes from respondents included: "There are a lot of branches of large retail chains and little supply of small independent companies", "I am looking forward to a diversity of products and being able to choose healthy alternatives. But the bottom line is that the shopping experience should not dominate or supplant the travel experience". Thus, the station area could profit from shops only by cautiously selecting the types of shops, and strictly controlling the overall number of shops as well as advertising.

Last, quadrant 4 shows a lower priority of quality indicators which were considered as less urgent to improve at Amsterdam Central station area, mainly including advanced services (A1-4), and land use and architecture (L4-6). The results of low importance could be due to the high proportion of local participation $(78.8 \%)$, fundamentally underestimating the importance of non-commuting related facilities and land use diversity. As tourists represent a high percentage of the users in Amsterdam Central station, their perceptions about these elements of place quality merit future investigation.

Combined with the conclusions of the path analysis, this study provides specific strategies that may improve user satisfaction at the Amsterdam Central station.

- The usage of Amsterdam Central station square seems the most urgent aspect to concentrate on, including help in emergency and accessibility facilities for seniors. The dissatisfaction is related to the ongoing renovations. Although the negative effects of the construction site on users are expected to disappear in the future due to the completion of the project, temporary routes with gender- and age-friendly facilities should be still considered to optimize the current usage of the square.

- The second priority goes to help in an emergency, especially in the case of female users. For example, during the nighttime, lighting and the presence of police/rail staff are crucial. Increasing police and introducing CCTV in specific areas, despite the controversy, are still worthy of discussion. In addition, although increasing the diversity of land use in the area is not considered important by users, it also acts as a crucial aspect of creating women-friendly environments.

- As for shops, although shopping activities are important to some users, the youth, nearby residents, and commuters, the actual responses to shopping services by the majority were not positive. Thus, improving the diversity/open hours/accessibility of shopping, which is expected by developers and local government, might require a reduction in other features of place quality such as transfer efficiency, which will negatively impact users' quality perceptions. The policy implication of this conclusion is that investments in shopping services must be selective, after satisfying the standard needs of food and drink options.

\section{Conclusions}

Using a case study of Amsterdam Central station, this study established a framework that defines place quality at station areas from users' perspective, confirming the previous theoretical and conceptual assumptions based on the literature mainly studied from a homogenous (passengers) point of view, and adding the perceptions of a more heterogeneous set of participants. Seven quality factors were identified as closely associated with place quality at station areas, namely, wayfinding (the spatial configuration that influences 
walking), transfer (services and the presence of amenities that relate to transfer), shopping, basic needs and safety, advanced services (non-commuting related services like Wi-Fi), land use and architecture, and art and decoration.

This study also examined how the perceived importance of quality factors changes with socio-demographic and visit characteristics using a path model. The results showed that the remaining six factors (except for land use and architecture) have significant correlations with certain users' characteristics, notably age and gender. Female and seniors are, in general, more attentive to place quality attributes. From a policy perspective, this reminds us to introduce more female and senior perspectives and participation into policymaking and planning to achieve gender- and age-friendly station areas that welcome and allow diverse groups of users to enjoy urban life. Finally, some specific policy recommendations were made for the administrator and operators of Amsterdam Central station area. To further develop the quality framework, it is advisable for future research to investigate station areas in other countries (for example, China), as users' attitudes and behaviors change with social norms and physical contexts.

Author Contributions: Conceptualization, J.D., O.D., P.v.d.B. and P.J.V.v.W.; methodology, J.D., O.D., P.v.d.B. and P.J.V.v.W.; software, J.D., O.D., P.v.d.B.; data analysis, J.D., O.D., P.v.d.B.; writing—original draft preparation, J.D., writing - review and editing, O.D., P.v.d.B., P.J.V.v.W. All authors have read and agreed to the published version of the manuscript.

Funding: This research was funded by China Scholarship Council (CSC).

Institutional Review Board Statement: All subjects gave their informed consent for inclusion before they participated in the study. The study was conducted in accordance with the Declaration of Helsinki, and the protocol was approved by the local Ethical Review Board (ERB) from the Built Environment Department of Eindhoven University of Technology (ERB2020BE46).

Informed Consent Statement: Informed consent was obtained from all subjects involved in the study.

Acknowledgments: We would like to thank the staff of the municipality (Gemeente) of Amsterdam for their help in distributing the questionnaire, and all the Amsterdam citizens who participated in the survey.

Conflicts of Interest: The authors declare no conflict of interest. The funders had no role in the design of the study; in the collection, analyses, or interpretation of data; in the writing of the manuscript, or in the decision to publish the results.

\section{References}

1. Bertolini, L.; Spit, T. Cities on Rails: The Redevelopment of Railway Stations and their Surroundings; Routledge: Lonodn, UK, 1998. [CrossRef]

2. Bertolini, L. Station areas as nodes and places in urban networks: An analytical tool and alternative development strategies. In Railway Development: Impacts on Urban Dynamics; Springer: Berlin/Heidelberg, Germany, 2008; pp. 35-57. [CrossRef]

3. Lee, C.; Moudon, A.V. The 3Ds+R: Quantifying land use and urban form correlates of walking. Transp. Res. Part D Transp. Environ. 2006, 11, 204-215. [CrossRef]

4. Hale, C.A.; Miller, M. Amenity and opportunity at rail stations. Aust. Plan. 2013, 50, 44-54. [CrossRef]

5. Peters, D. The renaissance of inner-city rail station areas as a key element in the contemporary dynamics of urban restructuring. Crit. Plan. 2009, 16, 163-185.

6. Stradling, S.G.; Anable, J.; Carreno, M. Performance, importance and user disgruntlement: A six-step method for measuring satisfaction with travel modes. Transp. Res. Part A Policy Pract. 2007, 41, 98-106. [CrossRef]

7. Cascetta, E.; Cartenì, A. The hedonic value of railways terminals. A quantitative analysis of the impact of stations quality on travellers behaviour. Transp. Res. Part A Policy Pract. 2014, 61, 41-52. [CrossRef]

8. Triggianese, M.; Roberto, C.; Baron, N.; Kuijper, J. Stations as Nodes: Exploring The Role Of Stations In Future Metropolitan Areas from a French and Dutch Perspective; TU Delft Open: Delft, The Netherlands, 2019. Available online: https://books.bk.tudelft.nl/index. $\mathrm{php} / \mathrm{press} /$ catalog/view /682/790/686-4 (accessed on 18 October 2021).

9. Marinov, M.; Lima, T.; Kühl, B.; Bogacki, A.; Onbasi, C. Analysis of customer services in railway passenger stations using a holistic method-Application to Newcastle central station. Transport. Probl. 2014, 9, 61-70.

10. Iseki, H.; Ringler, A.; Taylor, B.D.; Miller, M.; Smart, M. Evaluating Transit Stops and Stations from the Perspective of Transit Users. 2007. Available online: https://www.its.ucla.edu/wp-content/uploads/sites/6/2014/06/Appendix-C.pdf (accessed on 15 October 2021). 
11. de Oña, J.; de Oña, R.; Calvo-Poyo, F. A classification tree approach to identify key factors of transit service quality. Expert Syst. Appl. 2012, 39, 11164-11171. [CrossRef]

12. Lois, D.; Monzón, A.; Hernández, S. Analysis of satisfaction factors at urban transport interchanges: Measuring travellers' attitudes to information, security and waiting. Transp. Policy 2018, 67, 49-56. [CrossRef]

13. Nag, D.; BS, M.; Goswami, A.; Bharule, S. Framework for Public Transport Integration at Railway Stations and Its Implications for Quality of Life. Ssrn Electron. J. 2018, 1054, 1-12. [CrossRef]

14. Anciaes, P.; Jones, P. Transport policy for liveability-Valuing the impacts on movement, place, and society. Transp. Res. Part A Policy Pract. 2020, 132, 157-173. [CrossRef]

15. Hernandez, S.; Monzon, A. Key factors for defining an efficient urban transport interchange: Users' perceptions. Cities 2016, 50, 158-167. [CrossRef]

16. Loukaitou-Sideris, A.; Peters, D. What is Good Station-Area Planning? Lessons from Experts and Case Studies. Built Environ. 2020, 46, 422-439. [CrossRef]

17. Trip, J.J. What Makes A City? Planning For 'Quality of Place'. The Case of High Speed Train Station Area Redevelopment; IOS Press under the imprint Delft University Press: Amsterdam, The Netherlands, 2007.

18. Trip, J.J. Assessing Quality of Place: A Comparative Analysis of Amsterdam and Rotterdam. J. Urban. Aff. 2007, 29, 501-517. [CrossRef]

19. Esmaeilpoorarabi, N.; Yigitcanlar, T.; Guaralda, M. Place quality in innovation clusters: An empirical analysis of global best practices from Singapore, Helsinki, New York, and Sydney. Cities 2018, 74, 156-168. [CrossRef]

20. Murgaš, F.; Klobučník, M. Municipalities and Regions as Good Places to Live: Index of Quality of Life in the Czech Republic. Appl. Res. Qual. Life 2018, 11, 553-570. [CrossRef]

21. Groenendijk, L.; Rezaei, J.; Correia, G. Incorporating the travellers' experience value in assessing the quality of transit nodes: A Rotterdam case study. Case Stud. Transp. Policy 2018, 6, 564-576. [CrossRef]

22. Jaarverslag, N.S. Available online: https://dashboards.nsjaarverslag.nl/reizigersgedrag/amsterdam-centraal (accessed on 30 July 2021).

23. Willigers, J.; van Wee, B. High-speed rail and office location choices. A stated choice experiment for the Netherlands. J. Transp. Geogr. 2011, 19, 745-754. [CrossRef]

24. Zhen, F.; Cao, X.; Tang, J. Exploring correlates of passenger satisfaction and service improvement priorities of the ShanghaiNanjing High Speed Rail. J. Transp. Land Use 2018, 11, 559-573. [CrossRef]

25. Sands, B.D. The Development Effects of High-Speed Rail Stations and Implications for California. Built Environ. 1993, 19, 257-284. [CrossRef]

26. Starmans, M.; Verhoeff, L.; Heuvel, J.V.D. Passenger Transfer Chain Analysis for Reallocation of Heritage Space at Amsterdam Central Station. Transp. Res. Procedia 2014, 2, 651-659. [CrossRef]

27. Diao, M.; Zhu, Y.; Zhu, J. Intra-city access to inter-city transport nodes: The implications of high-speed-rail station locations for the urban development of Chinese cities. Urban. Stud. 2017, 54, 2249-2267. [CrossRef]

28. Du, J.; Druta, O.; J.V. van Wesemael, P. Place quality in High-Speed Rail station areas: Concept definition. Transp. Land Use 2021, $14,1-22$.

29. Zacharias, J.; Zhang, T.; Nakajima, N. Tokyo Station City: The railway station as urban place. Urban. Des. Int. 2011, 16, $242-251$. [CrossRef]

30. Zemp, S.; Stauffacher, M.; Lang, D.J.; Scholz, R.W. Generic functions of railway stations-A conceptual basis for the development of common system understanding and assessment criteria. Transp. Policy 2011, 18, 446-455. [CrossRef]

31. Van Hagen, M. Waiting Experience at Train. Stations. Available online: https://ris.utwente.nl/ws/portalfiles/portal/6066520/ thesis_M_van_Hagen.pdf (accessed on 18 October 2021).

32. Silva, J.D.A.E.; Bazrafshan, H. User Satisfaction of Intermodal Transfer Facilities in Lisbon, Portugal. Transp. Res. Rec. J. Transp. Res. Board 2013, 2350, 102-110. [CrossRef]

33. Diana, M. Measuring the satisfaction of multimodal travelers for local transit services in different urban contexts. Transp. Res. Part A Policy Pract. 2012, 46, 1-11. [CrossRef]

34. Cao, J.; Cao, X. Comparing importance-performance analysis and three-factor theory in assessing rider satisfaction with transit. J. Transp. Land Use 2017, 10, 65-68. [CrossRef]

35. Pongprasert, P.; Kubota, H. TOD residents' attitudes toward walking to transit station: A case study of transit-oriented developments (TODs) in Bangkok, Thailand. J. Mod. Transp. 2019, 27, 39-51. [CrossRef]

36. Wu, R. Passenger Experience of China's High Speed Rail (HSR) Service. Open J. Soc. Sci. 2018, 06, 253-259. [CrossRef]

37. Terzis, G.; Last, A. Guide-Urban Interchanges-A Good Practice Guide (Vol. Final). European Commission. Available online: https:/ / trimis.ec.europa.eu/sites/default/ files/project/documents/guide.pdf (accessed on 18 October 2021).

38. Chen, N.; Akar, G. How do socio-demographics and built environment affect individual accessibility based on activity space? Evidence from Greater Cleveland, Ohio. J. Transp. Land Use 2018, 10, 477-503. [CrossRef]

39. Farr, A.C.; Kleinschmidt, T.; Yarlagadda, P.K.; Mengersen, K. Wayfinding: A simple concept, a complex process. Transp. Rev. 2012, 32, 715-743. [CrossRef]

40. Filingeri, V.; Eason, K.; Waterson, P.; Haslam, R. Factors influencing experience in crowds-The participant perspective. Appl. Erg. 2017, 59, 431-441. [CrossRef] 
41. Horowitz, A.J.; Thompson, N.A. Generic objectives for evaluation of intermodal passenger transfer facilities. Transp. Res. Rec. 1995, 1503, 104-110.

42. de Oña, J.; de Oña, R.; Eboli, L.; Mazzulla, G. Index numbers for monitoring transit service quality. Transp. Res. Part A Policy Pract. 2016, 84, 18-30. [CrossRef]

43. Nathanail, E. Measuring the quality of service for passengers on the hellenic railways. Transp. Res. Part A Policy Pract. 2008, 42, 48-66. [CrossRef]

44. La Paix Puello, L.; Geurs, K. Adaptive stated choice experiment for access and egress mode choice to train stations. In Proceedings of the World Symposium of Transport Land Use and Research (WSTLUR), Delft, The Netherlands, 24-27 June 2014. Available online: https://ris.utwente.nl/ws/portalfiles/portal/5535542/WSTLUR_LaPaix_Geurs2014.pdf (accessed on 18 October 2021).

45. Punter, J. Urban Design and the English Urban Renaissance 1999-2009: A Review and Preliminary Evaluation. J. Urban. Des. 2011, 16, 1-41. [CrossRef]

46. Park, K.; Ewing, R.; Scheer, B.C.; Tian, G. The impacts of built environment characteristics of rail station areas on household travel behavior. Cities 2018, 74, 277-283. [CrossRef]

47. Darchen, S.; Tremblay, D.-G. What attracts and retains knowledge workers/students: The quality of place or career opportunities? The cases of Montreal and Ottawa. Cities 2010, 27, 225-233. [CrossRef]

48. Lawton, P.; Murphy, E.; Redmond, D. Residential preferences of the 'creative class'? Cities 2013, 31, 47-56. [CrossRef]

49. Calvo-Poyo, F.; de Oña, J.; Arán, F.; Nash, A. Light Rail Transit Experience in Madrid, Spain. Transp. Res. Rec. J. Transp. Res. Board 2013, 2353, 82-91. [CrossRef]

50. Calvo, F.; De Oña, J.; Arán, F. Impact of the Madrid subway on population settlement and land use. Land Use Policy 2013, 31, 627-639. [CrossRef]

51. Kickert, C.C.; Pont, M.B.; Nefs, M. Surveying Density, Urban Characteristics, and Development Capacity of Station Areas in the Delta Metropolis. Environ. Plan. B Plan. Des. 2014, 41, 69-92. [CrossRef]

52. Rahman, N.A.; Ghani, I.; Teh, M.Z.; Ibrahim, K. Rethinking Urban Public Space: Physical and Functional Analysis through Visual Surveys. IOP Conf. Ser. Earth Environ. Sci. 2020, 409, 012002. [CrossRef]

53. Li, C.; Yamamoto, T.; Morikawa, T. Analysis of user impressions of railway stations, focusing on the effects of adjunct retail facilities. Wit Trans. Built Environ. 2005, 77, 849-858.

54. Li, C.; Yamamoto, T.; Morikawa, T. The railway station as shopping destination. Conf. Traffic Transp. Stud. ICTTS 2004, 4, 715-725.

55. Nuworsoo, C.K.; Deakin, E. Transforming High-Speed Rail Stations to Major Activity Hubs: Lessons for California. In 88th Annu. Meet. Transp. Res. Board 2009, 1, 1-18.

56. Alexander, M.; Hamilton, K. A 'placeful' station? The community role in place making and improving hedonic value at local railway stations. Transp. Res. Part A Policy Pract. 2015, 82, 65-77. [CrossRef]

57. Diemer, M.J.; Currie, G.; De Gruyter, C.; Hopkins, I. Filling the space between trams and place: Adapting the 'Movement \& Place' framework to Melbourne's tram network. J. Transp. Geogr. 2018, 70, 215-227. [CrossRef]

58. Read, S.; Rooij, R. Integrating Mobility Environments in the City. Available online: http://https://www.corp.at/archive/CORP2 008_20.pdf (accessed on 18 October 2021).

59. Verhoef, P.; Bosma, J.; Urlings, T.; van der Boog, H.; Heijnsbroek, M.; Rijkes, H. Leveraging Big Data to Make Your Customers Happy. 2018. Available online: https://www.ns.nl/binaries/_ht_1525771196247/content/assets/ns-nl/over-ns/2018/customerexperience-analytics-ns.pdf (accessed on 18 October 2021).

60. van Hagen, M.; Bron, P. Enhancing the Experience of the Train Journey: Changing the Focus from Satisfaction to Emotional Experience of Customers. Transp. Res. Procedia 2014, 1, 253-263. [CrossRef]

61. Wang, B. How To Encourage Public Life In Squares of Chinese Railway Stations through Better Urban. Design; University College London: London, UK, 2014.

62. Dai, J.; Jia, S.; Lv, F. Evaluation of the Front Square of Harbin West Railway Station Based on POE Method. IOP Conf. Ser. Earth Environ. Sci. 2019, 234, 012003. [CrossRef]

63. Duckworth-Smith, A.; Babb, C. Indicating Quality of Place for station precinct development: Enhancing 'place' in the place/node model. In Proceedings of the 7th State of Australian Cities Conference, Gold Coast, Australia, 9-11 December 2015. Available online: https: / / apo.org.au/sites/default/ files/resource-files/2015-12/apo-nid63332.pdf (accessed on 18 October 2021).

64. Ewing, R.; Handy, S. Measuring the Unmeasurable: Urban Design Qualities Related to Walkability. J. Urban. Des. 2009, 14, 65-84. [CrossRef]

65. Ingvardson, J.B.; Nielsen, O.A. The influence of vicinity to stations, station characteristics and perceived safety on public transport mode choice: A case study from Copenhagen. Public Transp. 2021. [CrossRef]

66. Durmisevic, S.; Sariyildiz, S. A systematic quality assessment of underground spaces-Public transport stations. Cities 2001, 18, 13-23. [CrossRef]

67. Peek, G.-J.; van Hagen, M. Creating Synergy in and Around Stations: Three Strategies for Adding Value. Transp. Res. Rec. J. Transp. Res. Board 2002, 1793, 1-6. [CrossRef]

68. Iseki, H.; Taylor, B. Style versus Service? An Analysis of User Perceptions of Transit Stops and Stations. J. Public Transp. 2010, 13, 23-48. [CrossRef]

69. Coppola, P.; Silvestri, F. Assessing travelers' safety and security perception in railway stations. Case Stud. Transp. Policy 2020, 8 , 1127-1136. [CrossRef] 
70. Khan, M.F.; Aftab, S.; Fakhruddin. Quality of Urban Environment: A Critical Review of Approaches and Methodologies. Curr. Urban. Stud. 2015, 3, 368-384. [CrossRef]

71. Li, L.; Loo, B.P. Towards people-centered integrated transport: A case study of Shanghai Hongqiao Comprehensive Transport Hub. Cities 2016, 58, 50-58. [CrossRef]

72. Carreira, R.; Patrício, L.; Jorge, R.N.; Magee, C. Understanding the travel experience and its impact on attitudes, emotions and loyalty towards the transportation provider-A quantitative study with mid-distance bus trips. Transp. Policy 2014, 31, 35-46. [CrossRef]

73. Akiyama, T.; Okushima, M. Analysis of Railway User Travel Behaviour Patterns of Different Age Groups. IATSS Res. 2009, 33, 6-17. [CrossRef]

74. Hernandez, S.; Monzon, A.; de Oña, R. Urban transport interchanges: A methodology for evaluating perceived quality. Transp. Res. Part A Policy Pract. 2016, 84, 31-43. [CrossRef]

75. Gilbert, R.; Irwin, N.; Hollingworth, B.; Blais, P. Sustainable Transportation Performance Indicators (STPI) Projects. In Reports on Phase 3: CSTCTD. 2002. Available online: https: / / citeseerx.ist.psu.edu/viewdoc/download?doi=10.1.1.661.7698\&rep=rep1 \&type $=$ pdf (accessed on 18 October 2021).

76. Boyas, J.; Wind, L.H.; Kang, S.-Y. Exploring the relationship between employment-based social capital, job stress, burnout, and intent to leave among child protection workers: An age-based path analysis model. Child. Youth Serv. Rev. 2012, $34,50-62$. [CrossRef]

77. Gao, Y.; Rasouli, S.; Timmermans, H.; Wang, Y. Effects of traveller's mood and personality on ratings of satisfaction with daily trip stages. Travel Behav. Soc. 2017, 7, 1-11. [CrossRef]

78. Berry, R.E.; Williams, F.L. Assessing the Relationship between Quality of Life and Marital and Income Satisfaction: A Path Analytic Approach. J. Marriage Fam. 1987, 49, 107. [CrossRef]

79. Weijs-Perrée, M.; Dane, G.; Berg, P.V.D.; van Dorst, M. A Multi-Level Path Analysis of the Relationships between the Momentary Experience Characteristics, Satisfaction with Urban Public Spaces, and Momentary- and Long-Term Subjective Wellbeing. Int. J. Environ. Res. Public Health 2019, 16, 3621. [CrossRef] [PubMed]

80. Streiner, D.L. Figuring Out Factors: The Use and Misuse of Factor Analysis. Can. J. Psychiatry 1994, 39, 135-140. [CrossRef] [PubMed]

81. Ryff, C.D.; Keyes, C.L.M. The structure of psychological well-being revisited. J. Pers. Soc. Psychol. 1995, 69, 719-727. [CrossRef] [PubMed]

82. Hair, J.F.; Anderson, R.E.; Tatham, R.L.; Black, W.C. Multivariate Data Analysis, 6th ed.; Prentice Hall: Hoboken, NJ, USA, 2006.

83. Alreck, P.; Settle, R.B. Gender effects on Internet, catalogue and store shopping. J. Database Mark. 2002, 9, 150-162. [CrossRef]

84. Ng, W.-S.; Acker, A. Understanding Urban Travel Behaviour by Gender for Efficient and Equitable Transport Policies. Int. Transport. Forum 2018, 1, 1-19. [CrossRef]

85. Coluccia, E.; Louse, G. Gender differences in spatial orientation: A review. J. Environ. Psychol. 2004, 24, 329-340. [CrossRef]

86. Irschik, E.; Kail, E. Vienna: Progress towards a fair shared city. In Fair Shared Cities: The Impact of Gender Planning; Roberts, S.d.M., Ed.; Ashgate: London, UK, 2013; pp. 193-229.

87. Newman, M.C.; Kaszniak, A.W. Spatial Memory and Aging: Performance on a Human Analog of the Morris Water Maze. Aging Neuropsychol. Cogn. 2000, 7, 86-93. [CrossRef]

88. Bates, S.L.; Wolbers, T. How cognitive aging affects multisensory integration of navigational cues. Neurobiol. Aging 2014, 35, 2761-2769. [CrossRef] [PubMed]

89. Dholakia, R.R. Going shopping: Key determinants of shopping behaviors and motivations. Int. J. Retail. Distrib. Manag. 1999, 27, 154-165. [CrossRef]

90. Ibraeva, A.; Correia, G.H.D.A.; Silva, C.; Antunes, A.P. Transit-oriented development: A review of research achievements and challenges. Transp. Res. Part A Policy Pract. 2020, 132, 110-130. [CrossRef]

91. De Oña, J.; de Oña, R.; Eboli, L.; Mazzulla, G. Heterogeneity in Perceptions of Service Quality among Groups of Railway Passengers. Int. J. Sustain. Transp. 2015, 9, 612-626. [CrossRef]

92. Harms, L.; Bertolini, L.; Brömmelstroet, M.T. Spatial and social variations in cycling patterns in a mature cycling country exploring differences and trends. J. Transp. Health 2014, 1, 232-242. [CrossRef]

93. Falch, T.; Massih, S.S. The Effect of Education on Cognitive Ability. Econ. Inq. 2010, 49, 838-856. [CrossRef] [PubMed]

94. Machado-León, J.L.; de Oña, R.; Baouni, T.; de Oña, J. Railway transit services in Algiers: Priority improvement actions based on users perceptions. Transp. Policy 2017, 53, 175-185. [CrossRef] 